\title{
LEADING METHODOLOGICAL APPROACHES AND METHODS OF SCIENTIFIC KNOWLEDGE IN THE SPHERE OF COMPARATIVE MUSIC PEDAGOGY
}

\section{Stashevska I. O.}

\section{INTRODUCTION}

Intensive integration processes in the international education environment are causing growing interest of researchers to the study of achievements and shortcomings of educational systems of different countries with the purpose of their mutual enrichment and at the same time preserving the national cultural and educational identity.

Thereby, it has become an urgent need to improve and increase knowledge of the means of study, objective reflection and comparison of music-education phenomena and processes that occurred or are current in different cultures, countries, regions, taking into account the new conditions of the global society development and new requirements for the science of teaching.

The analysis of Ukrainian-speaking and Russian-speaking literature of the second half of XX - beginning of XXI century suggests that only a few papers are devoted to foreign music education experience in comparative perspective. Publications of the Soviet period in this area mostly contained an overview and general information. Their authors left aside comparative studies (for example, works by L. Barenboim, O. Bodina, I. Hadalova, Ye. Hurevych, I. Kriazheva, O. Novosad, H. Pozhydaiev, S. Stoianov, L. Schubert; collections of works edited by L. Barenboim, O. Apraksina, etc.).

Some research papers were distinguished by a strong ideological flavour, which was inherent in many publications on comparative education in Soviet times ${ }^{1}$.

\footnotetext{
${ }^{1}$ е.g. Корыхалова Н. П. Кризисные тенденции в буржуазном массовом музыкальном воспитании М.: Музыка. 1989. 112 с.
} 
In this decade, Ukrainian scientists have been striving to objective analysis of various aspects of foreign music education.

A significant contribution to formation of knowledge of the history of European music education has been made by the works of Ukrainian researchers S. Ulanova "Essays on the History of European Music Education and Upbringing: From Antiquity to the XIX Century" (2002), and O. Rostovskiy "Lectures on the History of West-European Music Pedagogy" $(2003)^{2}$.

Along with the significant intensification of research in the postSoviet scientific space of the last decades in the field of comparative education in recent years (I. Kolontaievska, I. Luhovska, O. Oleinikova, L. Riabov, I. Adamek, L. Vakhovskyi, T. Desiatov, V. Zhukovskyi, L. Ziaziun, T. Koshmanova, N. Lavrychenko, A. Maksymenko, O. Matvienko, H. Nikolai, L. Pukhovska, V. Chervonetskyi, O. Lokshyna, etc.), a small number of theses is devoted to the comparative analysis of music education experience of other countries (e.g. theses by A. Vilchkovska, H. Nikolai, R. Polukhin, A. Serhienko, I. Stashevska, A. Utkin and others $)^{3}$.

Taking into account the results of the analysis of the scientific literature in the post-Soviet space, it should be noted that musicpedagogical researches performed on materials of several countries remain relevant. This, in turn, necessitates the specification of the methodological apparatus of comparative music pedagogy, in particular the characteristics

\footnotetext{
2 Ростовський О.Я. Лекції 3 історії західноєвропейської музичної педагогіки. Ніжин: НДПУ ім. М. Гоголя. 2003. 193 с.; Уланова С. І. Нариси історії європейської музичної освіти і виховання: Від античності до початку ХІХ ст. К.: Знання України. 2002. 326 с.

3 Вільчковська А. Е. Розвиток теорії і практики музичного виховання учнів основних шкіл Польщі (1980-2000 рр.) : дис. ... канд. пед. наук : 13.00.01 / Вільчковська Анастасія Едуардівна. К. 2004.207 с.; Ніколаї Г. Ю. Розвиток музично-педагогічної освіти в Польщі (ХХ століття) : дис. ... доктора пед. наук : 13.00.01 / Ніколаї Галина Юріївна. К. 2008. 471 с.; Полухин Р. А. Сравнительный педагогический анализ тенденций развития общего музыкального образования в Республике Беларусь и Республике Польша : Вторая половина XX - начало XXI века : дис. ... канд. пед. наук : 13.00 .02 / Полухин Руслан Анатольевич. Брест. 2005. 250 с.; Сергиенко А. П. История становления и развития музыкального воспитания в Польше: (X - XX вв.) : дис. ... канд. пед. наук : 13.00.01/ Сергиенко Алла Петровна. К., 1993. 194 с.; Сташевська I. О. Розвиток музичної педагогіки в Німеччині (XX століття) : дис. ... доктора пед. наук : 13.00.01/ Сташевська Інна Олегівна. Луганськ. 2011. 550 с.; Уткин А. С. Теория и практика реализации музыкально-педагогической концепции 3. Кодая в современной школе : дисс. ... канд. пед. наук : 13.00.02 / Уткин Анна Сергевна. М. 2019. 291 с.
} 
of methodological approaches, the identification and classification of methods for comparative music-pedagogical research.

\section{Scientific approaches of music-pedagogical comparative studies}

Characterizing the scientific apparatus of comparative music pedagogy, first, it should be noted that the history and present state of the theory and practice of music education in different cultures, countries, regions in a comparative context are regarded as the subject of comparative music education.

Unfortunately, comparative music education research conducted on materials of several countries, is still absent in Ukraine. Underdeveloped are also the problems related to the methodology of comparative research in the field of music education. In this regard, the purpose of this article is to identify the subject, tasks, principles; to characterize methodological approaches; to reveal and classification of methods of comparative music education.

Accordingly, the main tasks of comparative music education research are: to study the process of historical development and current status of common and distinctive features of music education in certain cultures, countries, regions; to shape knowledge of trends and patterns of music education theory and practice in different parts of the world and globally; to identify prognostic opportunities and to develop strategies for improving the national system of music education taking into account negative and progressive international experience in this field. This ensures the implementation of descriptive, explanatory and prognostic functions of comparative music education.

Significant transformations in the methodology of comparative pedagogy of the last decades, characterized by the substitution of ideas of the world as a multiplicity of historically formed regional societies or nations that exist autonomously, to the understanding of transnational interdependence ( $\mathrm{H}$. Kornetov), by the emergence of the so-called world-wide approach (Ye. Brazhnyk) require from comparative researchers to consider their position not only in the national but also in 
the global - international context when analyzing foreign music and educational systems.

Providing theoretical and prognostic significance of comparative music education research requires the implementation of appropriate methodological grounds based on the existing norms, principles and techniques of scientific knowledge. Analysis of papers on the methodology of scientific knowledge, and in particular methodology of educational and comparative educational research (B. Vulfson, Ye. Brazhnyk, M. Vakhovskyi, O. Lokshyna, Z. Malkov, V. Kapranova, V. Kraievskyi, H. Nikolai, A. Novikov, A. Sbruieva and others) and comparative theses in the field of education, particularly music education, of the last decades in Ukraine and other countries of the post-Soviet scientific space allowed to reveal possible methodological principles, approaches and methods, as well as the specifics of information sources of the comparative music education research.

Thus, the methodological framework of comparative studies in the field of music education may be constituted by methodological principles of historicism, determinism, the interrelation of the objective and subjective, the integrity of the philosophical, general and specific scientific levels of methodological analysis, the unity of theory and practice, etc. Also the systems, synergetic, historical, cultural, civilization, anthropological, axiological, paradigmatic, comparative, parametric, intonational, communicative informational approaches and the approach of the general social context are worth mentioning.

We shall consider these methodological approaches in a greater detail in the context of the tasks of comparative music education.

Thus, systemic and synergistic approaches (I. Blauberh, E. Yudin, H. Khaken, I. Pryhozhyn) create opportunities for considering the subject of comparative music-pedagogical research as a complex structured open dynamic system. For example, the analysis of the peculiarities of the functioning of music education systems of certain countries, local musiceducational environments of certain regions or educational institutions, characteristic features of certain music-pedagogical concepts, etc. is carried 
out taking into account, first, their openness to permanent changes caused with socio-cultural factors, ability to self-organization and self-regulation, second, their hierarchical relations with other objects and phenomena, and, third, the specifics of the interaction of their own structural elements at different levels: conceptual, meaningful, operational, effective, etc.

The history and culture approach (M. Bakhtin, V. Bibler) provides the collection and description of historical facts, identifying musical and cultural traditions, evolutionary prerequisites, phases, trends and patterns of music education processes and phenomena in the context of general cultural life of the country studied in different historical periods that are significant for the research. It allows to take into account various intersections and confluence of music education ideas and practices with other socio-cultural phenomena - philosophy, aesthetics, general pedagogy, art, performing arts, religion, the media and others.

According to N. Borytko, from birth, a person is confronted with the experience of previous generations, which in a concentrated form is expressed in culture, sociocultural values, the interiorization of which in the pedagogical aspect "is ensured within the framework of a cultural approach through the organization of a pedagogically appropriate environment (public opinion, traditions, collective affairs, events, holidays, etc.)" ${ }^{\prime 4}$.

Thus, on the basis of the historical and cultural approach, the process of music education itself is positioned as a socio-cultural phenomenon, functioning according to the existing type of culture and aimed at transferring and developing music and cultural traditions by attracting a new generation to the values of music art, enriching the music and cultural experience and thereby forming the music culture of each member of society as an integral part of the spiritual culture of the whole society.

The civilization approach ( $\mathrm{H}$. Kornetov) involves the study of the history and current state of music education of certain countries on the basis of mutual influence of different cultural traditions in the context of music education process in the whole world.

\footnotetext{
${ }^{4}$ Борытко Н. М. Педагог в пространствах современного воспитания. Волгоград: Перемена, 2001. С. 9-10.
} 
The anthropological approach provides the investigation of music education processes and phenomena from the standpoint of a man and his needs.

The axiological approach (I. Ziaziun, M. Kahan, O. Sukhomlynska) enables to reveal in the scientific sphere the educational ideas about the value of musical training, education and development in the social and personal perspectives, and to disclose the role of music education in the context of preservation and transmission of music, cultural and human values, humane society development, etc.

The paradigmatic approach helps to identify music education paradigms that prevail in the investigated areas in certain historical periods with the help of the analysis of music education concepts and musical and educational reality, and to analyze them from the standpoint of the past. O. Nikolaieva discriminates the paradigmatic educational approach to the study of the history of music education, and emphasizes that it can be applied on several levels: the level of the main historical stages in the development of music education; the level of each specialization of music education (national, religious, social); the level of individual musical educational concepts ${ }^{5}$.

The comparative approach allows revealing the specifics of music education development in different parts of the world, ties, commonness and differences of music education models, regulations and characteristic features of their implementation in different historical periods. It also helps to identify positive and negative aspects, and possible ways of improving theory and practice of music education at the national level by comparing domestic and foreign music education experience.

The parametric approach (I. Luhovska), through the use of parametric estimation procedures and parametric comparison, opens opportunities for identifying features of the investigated objects on the basis of a unified system of qualitative and quantitative parameters, and, thus, it allows performing their element-by-element structural and functional comparative analysis.

\footnotetext{
Психология музыкальной деятельности: теория и практика. [под ред. Г. М. Цыпина]. М.: Издательский центр „Академия”. 2003. С. 300.
} 
The approach of general social context (L. Riabov, M. Vakhovskyi) can be used to identify the external socio-historical factors and conditions that determine the formation and evolution of musical and educational ideas, to compare views and conceptions of eminent personalities in music education through the interpretation of their quotations as products of activity in specific social, cultural and historical conditions.

The essence of the intonational approach (O. Nikolaieva) is supposed to trace in the history of music education the succession of fixed intonation guidelines in terms of the evolution of music art as the art of "the intonated meaning" (B. Asafiev) ${ }^{6}$. This approach involves consideration of music education of different cultures, countries, and regions with regard to its types. Their specific character is revealed due to the intonation analysis of any type of musical culture (national, social, religious, composing, performing, listeners', vocal, piano, conducting, culture of musical theory and music education, etc.). It also includes analysis of the correlation of music education systems with different musical styles.

In the context of the study, M. Vakhovskyi's opinion regarding the expediency of distinguishing quantitative and qualitative approaches in comparative pedagogical research deserves attention. The scientist rightly points out that it is more correct to speak "not about quantitative and qualitative analysis as separate methods of comparative pedagogy, but about quantitative and qualitative approaches to the study of educational problems, which are a specially formed set of research methods (quantitative or qualitative) for solving certain tasks"7. M. Vakhovsky also states that "the approach, unlike the method, determines the general scientific position of the researcher, which in turn forms the basis of the strategy of scientific search"»8.

Based on M. Vakhovskyi's position on the essence of quantitative and qualitative approaches in comparative-pedagogical research, it is possible

\footnotetext{
6 Психология музыкальной деятельности: теория и практика. [под ред. Г. М. Цыпина]. М.: Издательский центр „Академия”. 2003. С. 298.

7 Ваховський М. Л. Кількісний і якісний підходи в порівняльно-педагогічному дослідженні. Ocвima та педагогічна наука. 2016. № 1. С. 65.

${ }^{8}$ Ваховський М. Л. Кількісний і якісний підходи в порівняльно-педагогічному дослідженні. Ocвima та педагогічна наука. 2016. № 1. С. 65.
} 
to distinguish their role in the scientific knowledge of music-pedagogical problems. Thus, a quantitative approach allows establishing causality, identifying common laws, patterns and principles in music education. The qualitative approach helps to identify unique characteristics of musicpedagogical processes and phenomena, to consider them in dynamics and to form the basis for the interpretation of quantitative indicators.

In the context of comparative research in the sphere of training of future music teachers, $\mathrm{H}$. Nikolai emphasizes the methodological value of the communicative and informational approach, the application of which opens the possibilities for the analysis of the investigated process from the point of view of the polylog between its subjects and works of art, which reflect interpersonal relations 9 .

Indeed, the use of a communicative-informational approach in musicpedagogical comparative studies allows us to take into account the important functions of musical art in society - communicative and informational, and, on this basis, to study music-pedagogical processes and phenomena as in the context of subject-subject relations (for example, teacher - student, student - student, etc.), and from the perspective of subject-object interaction (for example, personality - a piece of music).

\section{Methods of comparative study of music-pedagogical processes and phenomena}

It is known that conducting any scientific research requires careful selection of research methods, and the logic of their application is justified, primarily by choosing the subject, objectives and tasks of the research, i.e. the set of research methods must correlate with the specific processes and phenomena investigated.

Comparative music education studies music education processes and phenomena in comparison, so the basic tools of comparative education research are general scientific methods and specific methods of scientific knowledge inherent in education. However, the interdisciplinary nature of

\footnotetext{
${ }^{9}$ Ніколаї Г. Музично-педагогічна компаративістика: шляхи розвитку. Порівняльно-педагогічні студіï. 2010. № 1-2. Режим доступу: http://pps.udpu.edu.ua/issue/view/947
} 
comparative music education also involves the use of methods of other scientific fields - history, philosophy, psychology, sociology, musicology, mathematics, source study, etc.

Various methods that can also be used for the realization of objectives and tasks of a research work on comparative music education were discovered with the help of analysis of scientific and educational literature on comparative education, namely the works of the leading Russian and Ukrainian comparative education experts B.Vulfson, Z. Malkova, O. Dzhurynskyi, Ye. Brazhnyk, V. Kapranova, A. Sbruieva and others, and also theses and comparative education research in Ukraine and Russia of the last decades (N. Abashkina, I. Adamek, L. Vakhovskyi, T. Desiatova, V. Zhukovskyi, L. Ziaziun, A. Ionova, E. Ismailova, I. Kolontaievska, T. Koshmanova, N. Lavrychenko, O. Leszczynskyi, I. Luhovska, A. Maksymenko, O. Matvienko, H. Nikolai, O. Oleinikova, L. Pukhovska, I. Radionova, A. Rastryhina, L. Riabov, S. Sinenko, V. Chervonetskyi, etc.).

The same as for any type of research such general scientific methods as theoretical analysis and synthesis, induction and deduction, abstraction and concretization, problematization, analogy, modeling, synthesis, systematization, and classification are very important for research on comparative music education. They allow identifying the key problem, forming the scientific subject-matter and the concept of the research, singling out essential characteristics, major trends and patterns of music education phenomena, summarizing theoretical and practical experience on the research, etc.

Collecting and processing factual material with various methods is a necessary basis for comparative music education research.

Thus, comparative music education research is impossible without studying government regulations, educational materials, curricula, teacher's documentation, and statistical data of the countries studied. The facts that are important to the knowledge and comparison of music education objects and phenomena are contained in fundamental historical, psychological, educational and musical works, encyclopedias and reference journals, memoirs, monographs, collections of scientific papers 
and conference proceedings, periodicals of past centuries and the present that can be found in domestic and foreign libraries, on the Internet, etc.

Studying the up-to-date foreign authors' publications that are devoted to the problems of history of music education concepts and practice development, organization of music education at traditional and specialized comprehensive school and nonschool educational establishments, music education of adults, professional training in musical culture and education is especially important for the versatile coverage of the subject of the research in the field of comparative music education.

Authentic sources of different historical periods, for example, ancient music theory treatises, music education papers, textbooks and manuals on music education, music dictionaries, articles in periodicals, collections of songs, etc. are valuable for objective analysis of foreign music education thought and practice in past centuries.

Translation of authentic literature is an important complementary method of comparative music education research. During the research the author has to be very careful when translating names and terms that, depending on the language, the historical period, and even the geographical region, may have different specific explication. One should also interpret terms of international music education systems with caution and integrate them into the national scientific and educational language carefully.

It should be noted that the degree of reliability of results of comparative music education research largely depends not only on the number of the sources studied, but on the completeness and accuracy of the information contained in them. It is almost impossible to process all the literature that is relevant to the research problem; that is why when working with sources, it is advisable to use the method of general array in combination with the selective method, when most of the sources selected according to certain criteria are analyzed. The selection of material for comparative music education research can be carried out by chronological, geographical, thematic or other characteristics.

Great assistance in studying various aspects of music education reality in the country or region investigated is provided by such empirical 
methods as observation, interviews (oral - interview, written - questioning, testing), and the peer review method. They help to reveal views on the subject of the research held by different groups of respondents: teachers, students and their parents, and heads of educational institutions. As a result, the researcher receives important factual material that on being compared with the information contained in regulatory documents and literature provides a relatively complete and objective view of the subject of the research.

Description of factual information is an essential method of research in the field of comparative music education. The issue of the interrelation of the factual material description and its analytical interpretation is relevant today. B. Vulfson rightly emphasized that excessive enthusiasm about facts comes at the expense of theoretical understanding, and, on the other hand, "such a reflection will be fruitful only if it is based on a thorough study of the specific facts and events" 10 . According to B. Vulfson, it is in the literature devoted to foreign problems that the ratio of factual material can often be higher than in works on the national education system; and the systematic description of new and little-known facts can serve as one of the important independent research tasks and an essential element of the comparative education research ${ }^{11}$.

Methods of Mathematical Statistics (registration, ranking, scaling, comparison) and also such sociological methods as sociometry, which allows to present the research results processed with mathematical methods in the form of tables, charts, graphs, and the content analysis, which is used for accurate and objective quantitative and qualitative content analysis of unsystematized information sources (regulations, nonfiction, interviews, questionnaires, etc.), are additional means of processing the received factual material.

The comparative analysis is a specific method used in the field of comparative education. As a complex method that includes a set of

\footnotetext{
10 Вульфсон Б. Л. Сравнительная педагогика. История и современные проблемы. М.: УРАО. 2003. C. 82.

11 Вульфсон Б. Л. Сравнительная педагогика. История и современные проблемы. М.: УРАО. 2003. C. 82.
} 
research techniques aimed at identifying the common and the different in education objects compared must be central when conducting the comparative music education research.

The method of binary comparison or binary analysis, which allows for "deep and detailed comparison of educational systems of two countries in which educational issues fit into a broad historical-cultural and socio-political context", is a technique of comparative analysis ${ }^{12}$. B. Vulfson distinguishes two types of binary comparison. The first involves the comparison of the national education system (as the basic one) and the foreign; and the second the comparison of two educational systems of foreign countries ${ }^{13}$.

According to the results of the analysis of the dissertation works of the post-Soviet countries, the studies in the field of foreign music pedagogy in them are still aimed at studying the music and pedagogical experience of individual countries and identifying the possibilities of improving the studied branch at the national level, taking into account the results of the scientific work carried out.

The relative homogeneity of the objects that are compared is essential for conducting the comparative analysis. Therefore, for comparison it is better to select the countries with relatively close historical and cultural traditions in the socio-economic, political, religious and other aspects. E. Ismailov singles out the principle of adequacy, "according to which the educational phenomena and processes bearing adequate general didactic regularities may be incorporated into the practice of the systems compared", as a necessary principle of contrastive analysis as a technique of comparative education analysis in this context ${ }^{14}$. Thus, as it was noted by A. Sbruieva, "when choosing the objects to compare many factors must be considered: the historical, cultural, economic, philosophical, religious, demographic, sociological, and teaching" ${ }^{\prime 15}$.

\footnotetext{
12 Вульфсон Б. Л. Сравнительная педагогика. История и современные проблемы. М.: УРАО. 2003. C. 55.

Вульфсон Б. Л. Сравнительная педагогика. История и современные проблемы. М.: УРАО. 2003. С. 55.

14 Исмаилов Э. Э. Сравнительно-педагогический анализ систем среднего профессионального образования Швеции и России : дис. ... д-ра пед. наук : 13.00 .08 / Исмаилов Эльхан Эюб оглы. Калининград. 2004. С. 17.

${ }^{15}$ Сбруєва А. А. Порівняльна педагогіка. Суми: СДПУ ім. А.С.Макаренка. 1999. С. 22.
} 
The comparison can be either synchronous, i.e. have a unified chronological framework, and asynchronous, when researchers compare the processes or phenomena that occurred in different historical periods.

The method of modeling is an effective technique that helps researchers to carry out the comparative analysis. For example, L. Riabov uses modeling for developing a working hypothetical model of a system of higher education of the developed countries as a reference for comparison $^{16}$.

An important condition for efficiency of the comparative analysis of music education processes and phenomena is a selection of certain parameters for their comparison.

The scientific study of the concept of the parametric approach to comparing of schooling in different countries was carried out in the thesis of I. Luhovska. The researcher proposed to use methods of parametric estimation and parametric comparison. According to the author, the technological procedure of parametric assessment is the identification of the real state of school education systems in different countries on the basis of a unified system of qualitative and quantitative parameters, and technological procedure of parametric comparison - element-by-element structural and functional comparative analysis of school education systems in different countries, based on the results of parametric evaluation ${ }^{17}$.

Thus, it is advisable to select the most essential elements for the comparison procedure (e.g., social and educational conditions, objectives, tasks, contents, methods and forms of music education activities, the specific character of music education systems management, etc.).

Comparative education research is carried out within the selected chronological framework and can cover different historical periods. In this context, scientific historical methods are an important means of conducting the comparative music education research: the analysis of sources and the

\footnotetext{
${ }^{16}$ Рябов Л. П. Сравнительно-педагогический анализ систем высшего профессионального образования развитых стран : автореф. дис. на соискание науч. степени д-ра пед. наук : спец. 13.00.01 «Общая педагогіка»/ Л. П. Рябов. М. 1998. 49 с.

17 Луговская И. Р. Параметрический подход к анализу систем школьного образования разных стран : дис. ... д-ра пед. наук : 13.00.01 / Луговская Ирина Робертовна. Санкт-Петербург. 2004. 393 с.
} 
historiographical analysis; the chronological and descriptive-analytical methods that involve consideration of the historiography of the subject of investigation, the search and processing of important encyclopedias, philosophical, psychological, educational, cultural, musicological, and regulatory sources, archival documents, collection, systematization and description of historical facts; the method of periodization, the comparative historical, retrospective and causal analysis that can detect the features of the evolution of music education ideas and the real state of music education practice in certain historical periods, define the main stages, political, economic, socio-cultural factors and prerequisites for shaping and development of music education phenomena; the paradigmatic method that is needed to identify the leading music education paradigms that prevailed in different historical periods and the main determinants of their change.

The forecasting is one of the key methods of comparative music education aimed at identifying ways of improvement and prospects of further development for the national theory and practice of music education, taking into account the results of the comparative research conducted.

Concluding the consideration of the methods of scientific knowledge that can be used in the comparative music education research, it should be noted that there is not a strictly regulated set of methods that are specific only for comparative education, and in particular music education research. Researchers have been implementing both general scientific and special methods that are characteristic of certain scientific fields and can be adapted for solving specific research problems.

However, in order to consolidate and systematize the material given above, we will try to classify the methods of comparative education research that can be an effective means of scientific knowledge particularly in the field of comparative music education.

The analysis of publications that reveal the foundations of methodology of scientific knowledge ${ }^{18}$ indicates the absence of a unified classification of the education research methods.

\footnotetext{
18 Брызгалова С. И. Введение в научно-педагогическое исследование. Калининград: Изд-во КГУ. 2003. С. 54; Загвязинский В. И. Методология и методика дидактического исследования. М.: Педагогика.
} 
Concerning methods of comparative education research, the wellknown Russian comparative scientist B.Vulfson singles out two groups of methods - general scientific and special (appropriate for the object investigated and the main sources studied $)^{19}$.

As noted by O. Novikov, to discover a class of objects means to identify those essential characteristics that are common to all the objects that make up this class ${ }^{20}$.

Thus, the classification of scientific methods must be based on their distribution according to certain criteria. The process of identifying these features can be performed by different criteria, for example:

- by the level of scientific knowledge: empirical and theoretical;

- by the stages of the research: diagnostic, information gathering, organizational, interpretative, generalizing, etc.;

- by way of displaying knowledge: descriptive and explanatory;

- by the level of methodological analysis: philosophical, generalscientific, concrete-scientific, subject-applied (disciplinary), interdisciplinary;

- by the specifics of the substantive essence of the studied objects: sociological, mathematical, humanitarian, etc.

- by way of application: simple and complex.

However, none of these options can cover the whole range of comparative pedagogy methods. Thus, in order to systematize the basic methods that can be applied for accomplishing objectives and solving tasks of the comparative education research, and particularly music education research, we propose the following complex structured classification based on several criteria: research stages, levels of scientific knowledge and methodological analysis (Table 1).

1982. С. 104.; Краевский В. В. Общие основы педагогики. М.- Волгоград: Перемена. 2002. С. 144-156; Кыверляг А. А. Методы исследований в профессиональной педагогике. Таллин: Валгус. 1980. 334 с.; Новиков А. М. Докторская диссертация? М.: Эгвес. 2003. С. 57-58; Рудницька О. П., Болгарський А. Г., Свистєльнікова Т. Ю. Основи педагогічних досліджень. К.: НПУ імені М. П. Драгоманова. 1998. С. 52. та iн. C. 80 .

Вульфсон Б. Л. Сравнительная педагогика. История и современные проблемы. М.: УРАО. 2003.

${ }^{20}$ Новиков А. М. Докторская диссертация? М.: Эгвес. 2003. С. 37. 


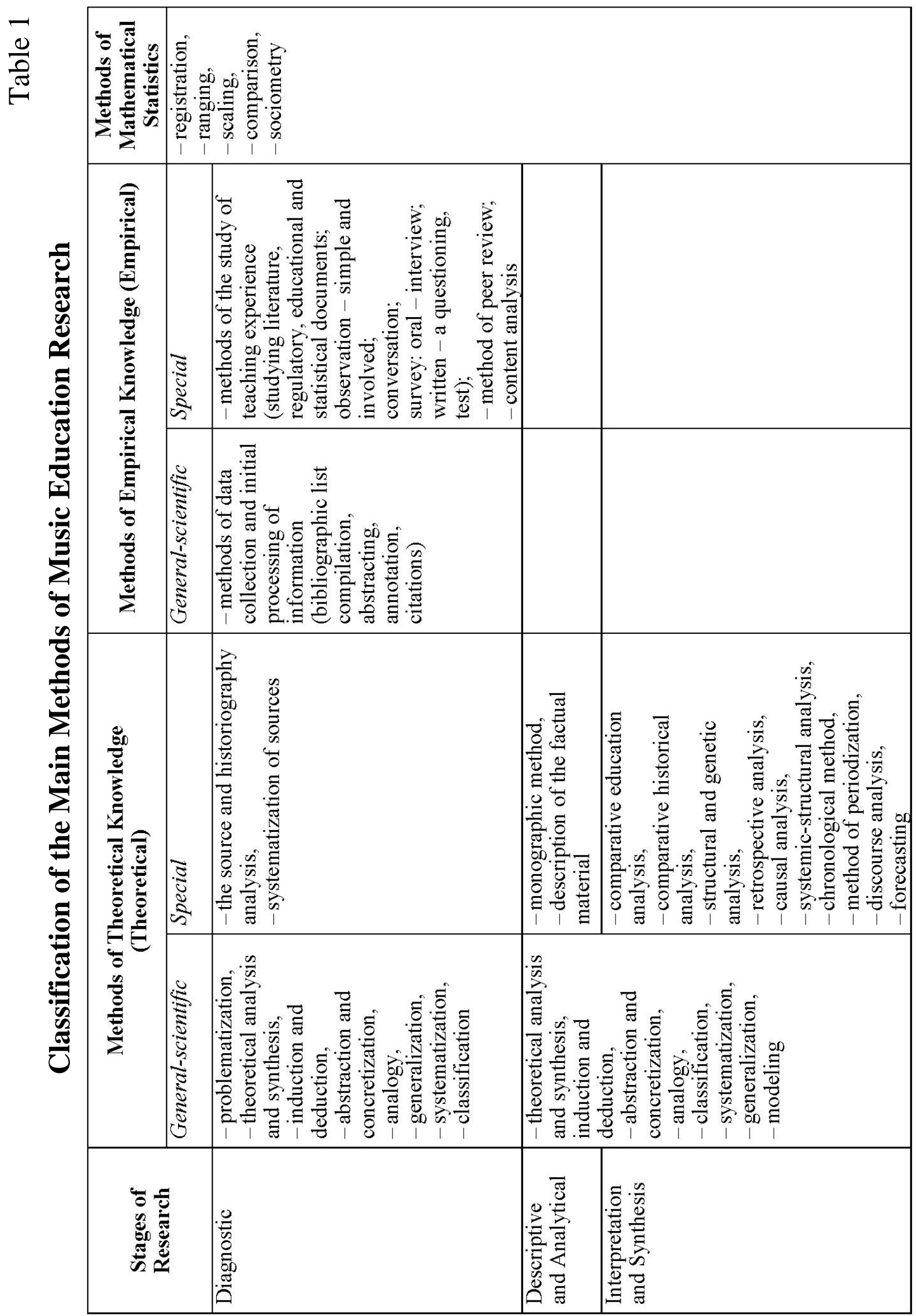


It should be pointed out that the selection of classification groups is arbitrary, because, as it is known, all the methods chosen for a particular research should inter-relate and complement each other.

The classification of methods of the comparative education research in Table 1 does not suggest that it is comprehensive and complete. The main purpose of the author is drawing attention of comparative education researchers to the existing problem, as well as the pertinence of further expansion and streamlining of comparative music education methods, because the breadth of their spectrum and the degree of consistency between them are essential factors that affect the results of the research and allow to obtain the most complete and objective information about the subject of the research.

\section{CONCLUSIONS}

Thus, the crucial role of music education in the transmission of musical and cultural traditions and formation of music culture of the younger generation, as well as in the significant impact on the humanization of society, requires the study and implementation of the best achievements of world music education in the national system of music education. However, the analysis has shown that a coherent concept of the mechanism of comparative studies of music education systems of different countries does not yet exist in science of the post-Soviet countries. The characterization of individual components of the comparative music education methodology carried out in this article, of course, does not exhaust all aspects of the methodology of comparative music education research, and requires further detailed development.

It is advisable in this context to create a methodology for comparative analysis of music and educational systems of different countries with the purpose of their enrichment, the development of new methodological approaches specific for comparative music pedagogy, a thorough study of the possibilities of using scientific methods of certain scientific disciplines (history, philosophy, psychology, sociology, mathematics, source studies, etc.) in the process of comparative music and pedagogical research, a 
detailed description of the selection and processing characteristics in the source base, determining the most significant parameters for the assessment and comparative analysis of music and pedagogical processes and phenomena.

\section{SUMMARY}

The necessity of specifying the methodological apparatus of comparative music pedagogy, in particular the characteristics of methodological approaches, definition and classification of methods of comparative music pedagogical research, was actualized in the article. It was found that the subject of comparative music pedagogy is the history and current state of music education theory and practice in different cultures, countries and regions in a comparative perspective. It is emphasized importance to consider the positions of foreign music and educational systems in the process of the analysis not only in the national but also in the global - international context. The key tasks and principles of comparative research in the sphere of music pedagogy were specified. The scientific approaches of comparative music pedagogy are characterized: systematic, synergetic, historical and cultural, civilizational, anthropological, axiological, paradigmatic, comparative, parametric, approach of the general social context, intonational, communicative-informational, etc. Various methods have been identified that can be used to accomplish the goals and objectives of research in the sphere of music-pedagogical comparative studies. In order to systematize the basic methods of comparative music-pedagogical research, their complex-structured classification was carried out, which is based on the selection of certain criteria: stages of research, levels of scientific knowledge and levels of methodological analysis. Perspective directions of further development in methodological foundations of comparative music pedagogy have been determined. 


\section{REFERENCES}

1. Борытко Н. M. Педагог в пространствах современного воспитания : монография. Волгоград: Перемена. 2001. 214 с.

2. Брызгалова С. И. Введение в научно-педагогическое исследование : Учебное пособие. [3-е изд., испр. и доп.]. Калининград: Изд-во КГУ. 2003. 151 с.

3. Ваховський М. Л. Кількісний і якісний підходи в порівняльнопедагогічному дослідженні. Освіта та педагогічна наука. 2016. № 1. C. 64-68.

4. Ваховський М. Методологічні аспекти порівняльного аналізу педагогічних ідей Г. Манна та К. Ушинського. Педагогіка, психологія та медико-біологічні проблеми фізичного виховання $i$ спорту. 2008. № 10. C. 26-30.

5. Вільчковська А. Е. Розвиток теорії i практики музичного виховання учнів основних шкіл Польщі (1980-2000рр.) : дис. ... канд. пед. наук : 13.00.01 / Вільчковська Анастасія Едуардівна. К. 2004. $207 \mathrm{c}$.

6. Вульфсон Б. Л. Сравнительная педагогика. История и современные проблемы. М.: УРАО. 2003. 232 с.

7. Загвязинский В. И. Методология и методика дидактического исследования. М.: Педагогика. 1982. 159 с.

8. Исмаилов Э. Э. Сравнительно-педагогический анализ систем среднего профессионального образования Швеции и России : дис. ... д-ра пед. наук : 13.00.08 / Исмаилов Эльхан Эюб оглы. Калининград, 2004. 241 c.

9. Комарова А. А. Сравнительный анализ систем обучения иностранным языкам в военных вузах России и США : автореф. дис. на соискание науч. степени канд. пед. наук : спец. 13.00.01 / А. А. Комарова. Нижний Новгород. 2003. 28 с.

10. Корыхалова Н. П. Кризисные тенденции в буржуазном массовом музыкальном воспитании. М.: Музыка. 1989. 112 с.

11. Краевский В. В. Общие основы педагогики. М.- Волгоград: Перемена. 2002. 163 с. 
12. Кыверляг А. А. Методы исследований в профессиональной педагогике. Таллин: Валгус. 1980. 334 с.

13. Луговская И. Р. Параметрический подход к анализу систем школьного образования разных стран : дис. ... д-ра пед. наук : 13.00.01 / Луговская Ирина Робертовна. Санкт-Петербург. 2004. 393 с.

14. Ніколаї Г. Музично-педагогічна компаративістика: шляхи розвитку. Порівняльно-педагогічні студї. 2010. № 1-2. Режим доступу: http://pps.udpu.edu.ua/issue/view/947

15. Ніколаї Г. Ю. Розвиток музично-педагогічної освіти в Польщі (XX століття) : дис. ... доктора пед. наук : 13.00.01 / Ніколаї Галина Юріївна. К. 2008. 471 с.

16. Новиков А. М. Докторская диссертация? М.: Эгвес. 2003. $120 \mathrm{c}$.

17. Полухин P. А. Сравнительный педагогический анализ тенденций развития общего музыкального образования в Республике Беларусь и Республике Польша : Вторая половина XX - начало XXI века : дис. ... канд. пед. наук : 13.00.02 / Полухин Руслан Анатольевич. Брест. 2005. 250 с.

18. Психология музыкальной деятельности: теория и практика : [учеб. пособ. для студентов муз. фак. высш. пед. учеб. заведений] / [под ред. Г. М. Цыпина]. М.: Издательский центр «Академия». 2003. $368 \mathrm{c}$.

19. Ростовський О.Я. Лекції 3 історії західноєвропейської музичної педагогіки : [навч. посіб.]. Ніжин: НДПУ ім. М. Гоголя. 2003. 193 c.

20. Рудницька О. П., Болгарський А. Г., Свистєльнікова Т. Ю. Основи педагогічних досліджень. К.: НПУ імені М. П. Драгоманова. 1998. 143 c.

21. Рябов Л. П. Сравнительно-педагогический анализ систем высшего профессионального образования развитых стран : автореф. дис. на соискание науч. степени д-ра пед. наук : спец. 13.00.01 «Общая педагогіка» / Л. П. Рябов. М., 1998. 49 с. 
22. Сбруєва А. А. Порівняльна педагогіка : [навч. посіб.]. Суми: СДПУ ім. А. С. Макаренка. 1999. 301 с.

23. Сергиенко А. П. История становления и развития музыкального воспитания в Польше: (X - XX вв.) : дис. ... канд. пед. наук : 13.00.01/ Сергиенко Алла Петровна. К. 1993. 194 с.

24. Сташевська І. О. Розвиток музичної педагогіки в Німеччині (XX століття) : дис. ... доктора пед. наук : 13.00 .01 / Сташевська Інна Олегівна. Луганськ. 2011. 550 с.

25. Уланова С. І. Нариси історії європейської музичної освіти $\mathrm{i}$ виховання: Від античності до початку XIX ст. К.: Знання України. 2002. $326 \mathrm{c}$.

26. Уткин А.С. Теория и практика реализации музыкальнопедагогической концепции 3. Кодая в современной школе : дисс. ... канд. пед. наук : 13.00.02 / Уткин Анна Сергевна. М. 2019. 291 с.

\section{Information about the author:} Stashevska I. O.

Doctor of Pedagogical Sciences, Professor, Honored Art Worker of Ukraine, Vice-rector for Educational Work, Kharkiv State Academy of Culture 4, Bursatskyi uzviz, Kharkiv, Ukraine 